\title{
An Empirical Investigation of the Relationship between Corporate Governance Mechanisms, CEO Characteristics and Listed Companies' Performance
}

\author{
Georgeta Vintilă $^{1}$ \& Ştefan Cristian Gherghina ${ }^{1}$ \\ ${ }^{1}$ Department of Finance, Faculty of Finance, Insurance, Banking and Stock Exchange, The Bucharest University \\ of Economic Studies, Bucharest, Romania \\ Correspondence: Ştefan Cristian Gherghina, The Bucharest University of Economic Studies, 6 Romana Square, \\ district 1, postal code 010374, postal office 22, Bucharest, Romania. Tel: 40-21-319-1900. E-mail: \\ gherghina_stefan@yahoo.com
}

$\begin{array}{lcc}\text { Received: July 3, 2012 } & \text { Accepted: August 3, 2012 } & \text { Online Published: September 3, } 2012 \\ \text { doi:10.5539/ibr.v5n10p175 } & \text { URL: http://dx.doi.org/10.5539/ibr.v5n10p175 }\end{array}$

\begin{abstract}
This paper examines the impact of corporate governance mechanisms and CEO characteristics on U.S. listed companies' performance. The corporate governance mechanisms are: shareholdings of insiders, shareholdings of the institutional investors and mutual funds, board size and the number of independent directors in the board. We used as performance measures the following: Tobin's Q, return on assets, return on equity, price to book value and price earnings ratio. Additionally, we considered the impact of CEOs characteristics on companies' performance. These characteristics are: CEO status regarding the possibility of holding multiple functions, the CEO's possibility of being the founder of the company that he manages, state of residence, age and tenure in $\mathrm{CEO}$ position. Also we controlled for firm size, firm age and gearing. Our findings suggest mixed results between corporate governance and firm performance.
\end{abstract}

Keywords: corporate governance, firm performance, corporate governance mechanisms, CEO characteristics, agency theory

\section{Introduction}

Corporate governance mechanisms and controls are designed to reduce the inefficiencies that arise from moral hazard and adverse selection. However, there are internal corporate governance controls (through which all the activities from the companies are monitored and through which are taken corrective action to accomplish the goals of the organisation), and external corporate governance controls (which encompass the controls external stakeholders exercise over the organization). According to Aggrawal and Knoeber (1996), "agency problems arise within a firm whenever managers have incentives to pursue their own interests at shareholder expense". Besides, there are corporate governance mechanisms which could reduce this deficiency. A prominent mechanism is represented by the shareholdings of institutional investors which increase the managerial monitoring process and improves the companies' performance, as the presence of independent directors, from outside of the company, in the board. However, the debt financing could determine the increase of companies' performance through the monitoring process by the creditors. The managerial labor market could impulse the managers to take into consideration their reputation regarding possible future relations with another employers, this fact determining the improvement of the performance. Likewise, the threat of displacement manifested from the market for corporate control, could lead to a weighty discipline on managers with low performance (Aggrawal \& Knoeber, 1996).

Corporate governance is a key element in the improvement process of the efficiency and in the economic development process, additionally determining the investors' protection. According to Shleifer and Vishny (1997), corporate governance is defined in terms of the ways in which suppliers of finance to a firm assure themselves of a good return to their investment. Also, through corporate governance are identified the mechanisms that restrict the agency costs, by checking the managerial unobtrusive and by aligning the shareholders' and managers' objectives. Corporate governance is the process and structure through which a firm's business and affairs are managed by enhancing business prosperity and corporate accountability with the 
ultimate objective of enhancing shareholder's wealth (Mir \& Nishat, 2004). On the other hand, firms with weaker governance structures have greater agency problems. Also, the CEOs from the firms with greater agency problems receive greater compensation and the firms with greater agency problems perform worse (Core et al., 1999).

The objective of this study is the investigation of the relationship between corporate governance mechanisms and the U.S. listed companies' performance, also considering some CEO characteristics. However, this paper have two major contributions. First, we assess the impact of corporate governance mechanisms on firm performance, through the use of quadratic OLS regressions. And, second, we assess the impact of CEO characteristics on firm performance, but without considering the interaction firm performance-CEO turnover, as in previous studies. Also we use five proxies for firm performance, both accounting measures and measures related to capital market performance.

The remainder of the paper is organized as follows. Section 2 provides prior research on corporate governance mechanisms, CEO characteristics and firm performance. Section 3 presents the development of the research hypotheses. Section 4 presents the description of the database and the research methodology. Section 5 provides descriptive statistics regarding all the variables from the study. Section 6 presents the empirical results and discussion. Section 7 concludes the paper.

\section{Literature Review}

The studies conducted until now mentions the fact that both market mechanisms and internal mechanisms of the companies, could be used in order to harmonize the interest between managers and stakeholders. Both managerial labor market and market for corporate control are exerting pressure in and out of the companies, in order to harmonize the interests. According to Fama (1980), "the firm is viewed as a team whose members act from self-interest but realize that their destinies depend to some extent on the survival of the team in its competition with other teams", the productivity of each member manifesting a direct effect on the team and on the other members. Thus, through the team, every manager has stimulants in order to monitor the behaviour of the other managers, being subordinates or superiors.

However, the studies regarding the relationship between corporate governance and firm performance are wide, but the results are not convergent. We distinguish streams which sustain a positive relationship between corporate governance and firm performance, while others sustain a negative relationship or a lack of association between corporate governance and firm performance. The positive correlation is based on the theory that an efficient board of directors could reduce significantly the agency costs (Mashayekhi \& Bazaz, 2008). Besides, the legal systems, the political stability, the reduced size of the markets, the corporate ownership and the type of the individual financial systems, are the differences manifested through the institutional dispositions, between developed and developing countries. Corporate governance considers the mechanisms that reduce the agency costs, controlling the freedom of action from the manager's perspective and aligning the interests of the owners and managers. According to Shleifer and Vishny (1997), "corporate governance mechanisms are economic and legal institutions that can be altered through political process".

The studies which research the relationship between corporate governance and firm performance are divided into two categories. There are studies which sustain the existence of a relationship between corporate governance and firm performance, called "state of imbalance", because the companies could major their value by modifying their corporate governance regimes. Also, there are studies which contradict the existence of a relationship between corporate governance and firm performance, named "balanced state", because the managers could not intensify the value of the companies by modifying the corporate governance structures.

Morck, Schleifer \& Vishny (1987), McConnell \& Servaes (1990) and Core \& Larcker (2002) identified the fact that corporate governance structures are influencing the value of the companies. Contrary, Demsetz \& Lehn (1985) and Agrawal \& Knoeber (1996) suggested the fact that the owners and the managers are choosing a variety of corporate governance structures, every of them maximising the value of the company, but none of them is not correlated with corporate performance.

An argument in order to solve the agency problem results from the concerns regarding the shareholdings of the insiders. However insider ownership can cause two types of fully differentiated behaviour: convergence of interests with shareholders and the entrenchment effect. Jensen and Meckling (1976) sustained the fact that as insider ownership is growing, the tendency of owners to consume company resources is decreasing. In this way, the insiders' interests and those of shareholders are aligned. On the other side, conflicts between owners and managers tend to disappear, and the hypothesis of convergence of interests is accepted. Additionally, the natural tendency of managers is to use company resources in their own interests, which may conflict with those of 
external shareholders. Conversely, when insiders hold a percentage of the capital of the company that is large enough to give them voting power or influence, they can achieve their own objectives other than the maximization of value without compromising either their jobs or their salaries. Also, we can identify an entrenchment effect on the part of insiders, which means that too high a percentage of insider ownership has a negative impact on business performance. According to Itturalde et al. (2011), the existence of these two widely different effects suggests a nonlinear relationship between insider ownership and the value of the company. The convergence of interests hypothesis and the entrenchment effect hypothesis serve as an explanation for the bell-shaped relationship between insider ownership and firm value found by McConnell \& Servaes (1990) or the piecewise-linear relationship discovered by Morck, Shleifer \& Vishny (1988) in their previous study.

Demsetz (1983) asserted that ownership structure is an endogenous outcome of the maximization process and every change in ownership level is made in order to maximize the shareholder profit. Therefore, the ownership concentration and the profit rate are unrelated. Additionally, Demsetz \& Lehn (1985) and Demsetz \&Villalonga (2001) found that ownership concentration and firm performance are unrelated. The non-linear impact of ownership on firm performance was also found by Holderness et al. (1999).

Ownership concentration considers the proportion of the shares held by the greatest shareholders. A high ownership concentration tend to manifest pressure on managers in order to adopt a corporate behavior which must determine the maximisation of their wealth. The performance of the companies would be impaired (improved) in case of a dispersed (concentrated) shareholding. The high magnitude of concentration of the shareholding is positively correlated with performance (Berle \& Means, 1932). Morck et al. (1988), McConnell \& Servaes (1990), and Holderness et al. (1999) all find firm value to rise with low levels of managerial ownership and to fall with higher levels of managerial ownership. Chaganti \& Damanpour (1991) and Lowenstein (1991) found little evidence that institutional ownership is correlated with firm performance. However, Shleifer \& Vishny (1997) argued that ownership concentration can serve as a substitute for weak investor protection rights. Consequently, ownership concentration should be positively related to corporate performance especially in environments of weak legal systems.

The size of the board of directors is another mechanism which could reduce the agency problem. Also, there are arguments which sustain the boards composed from a lower number of members. The most important function of a board of directors is to control the costs resulted from the separation of ownership and control (Fama \& Jensen, 1983). Thus, it was identified an inverse relationship between the board size and the value of the company (Yermack, 1996). The board of directors is realizing the monitoring function in the shareholder's name because of the inconveniences encountered by them in exerting the control, in case of dispersed structures of the shareholders. According to John \& Senbet (1997), "while the board's capacity for monitoring increases as more directors are added, the benefit may be outweighted by the incremental cost of poorer communication and decision-making associated with larger groups". Lipton \& Lorsch (1992) claimed the existenece of small boards, and recommended that board size should be limited to seven or eight members. Also, Eisenberg et al. (1998) asserted that when board size increases, the difficulties in coordination and communication increase. This fact causes greater agency problems and costs. Jensen (1993) stated that "keeping boards small can help improve their performance. When boards get beyond seven or eight people they are less likely to function effectively and are easier for the CEO to control". The companies with boards of directors composed between six and fifteen members, recorded better values of return on equity rate and profit margin, relative to other companies with lower size of the board of directors (Brown \& Caylor, 2004). Additionally, the boards composed of a greater number of members manifests a significant and negative influence on the future return on assets (Beekes, Hong \& Owen, 2010).

In order to improve the agency problem, another mechanism which is proposed is the board structure. However, empirical studies of the effect of board structure on firm value or performance generally show results either mixed or opposite to what would be expected from the agency cost argument. There are some studies which found better performance for firms with boards of directors dominated by outsiders (Rosenstein \& Wyatt, 1990; Millstein \& MacAvoy, 1998), and others which found no such relationship in terms of accounting profits or firm value (Hermalin \& Weisbach, 1991; Bhagat \& Black, 2000; Weir \& Laing, 2001). Baysinger \& Butler (1985) found that board with more outside directors performed better than other firms. Hermalin \& Weisbach (1991) found no significant correlation between board independence and Tobin's Q or EBIT. Ezzamel \& Watson (1993) found that outside directors were positively associated with profitability among a sample of U.K. firms. Also, Klein (1998) found no correlation between overall board independence and return on assets, productivity, or stock return. Bhagat \& Black (2000) found evidence that firms suffering from low profitability respond by increasing the independence of their board of directors, but no evidence that this strategy works if those firms 
with more independent boards achieve improved profitability. Their results are consistent with poor performance prompting firms to adopt more independent boards, but suggests that firms do not achieve superior performance (and may possibly achieve even worse performance) as a result of this change in board composition.

Thus, the board structure is not correlated with the corporate performance, while the board size is negatively correlated with performance (Hermalin \& Weisbach, 2001). Also, there was not recorded an improvement of Tobin's Q rate in the companies with independent board of directors, similarly Bhagat \& Black (2000) and Hermalin \& Weisbach (2001), but resulted that the companies with independent board of directors recorded better values of return on equity rate, profit margin, dividend yield and greater stock repurchases (Brown \& Caylor, 2004). The independence of the board is negatively correlated with the current and future operational performance (Bhagat \& Bolton, 2008). "The optimal board structure is determined by the trade-off between maximizing the incentive for insiders to reveal their private information, minimizing coordination costs among outsiders and maximizing the ability of outsiders to reject inferior projects" (Raheja, 2005).

According to Belkhir (2004), it is considered that separating the titles of Chairman and CEO will reduce agency costs and will improve firm performance. The explanation is given by the fact that when the CEO is also the chairman of the board, the power within the firm is concentrated in one person's hands. This situation allows the CEO to control information available to other board members. The board becomes under the control of managers, which prevents it from effectively accomplishing its tasks of hiring, eventually firing, and rewarding top executive officers, and to ratify and monitor important decisions. Given the decrease in the effectiveness of the board, the potential agency costs resulting from the separation of ownership and decision making are exacerbated. Also, Jensen (1993), stated that "the function of the chairman is to run board meetings and oversee the process of hiring, firing, evaluating, and compensating the CEO. Clearly, the CEO cannot perform this function apart from his or her personal interest. Without the direction of an independent leader, it is much more difficult for the board to perform its critical function. Therefore, for the board to be effective, it is important to separate the CEO and chairman positions".

On the other hand, stewardship theorists counter-argue that CEO duality positively influence firm performance. The managers are inherently trustworthy and are good stewards of company resources (Fama \& Jensen, 1983). However, Rechner \& Dalton (1991), for 141 corporations over a 6-year time period, found that firms with CEO duality performed better. Also, Brickley et al. (1997) argued that separating the titles will reduce agency costs in corporations and will improve performance. Bhagat \& Bolton (2008) stated the fact that the separation between the Chief Executive Officer and the chairman of the company is positively correlated and statistically significant with the current and future operational performance.

However, Daily \& Dalton (1992), examined the organizational agent/firm performance linkage focusing specifically on the role of founder Chief Executive Officers (CEOs) and the composition of the boards of directors, for entrepreneurial firms. They found no relationship between CEO duality and firm performance. Also Chen et al. (2008), didn't find a significant relationship between CEO duality and firm performance nor improvement in firm performance after the change in leadership structure.

Adams et al. (2009), found strong evidence that founder-CEO status is endogenous in performance regressions and that good performance makes it less likely that the founder retains the CEO title. After factoring out the effect of performance on founder-CEO status, they identified a positive causal effect of founder-CEOs on firm performance that is quantitatively larger than the effect estimated through standard OLS regressions. However, Villalonga \& Amit (2006), Palia et al. (2008) and, Fahlenbrach (2009) all find a positive relation between founder-CEOs and firm performance.

Miller \& Shamsie (2001) found that product line experimentation declines over the course of executive tenures. Also, they found that there is an inverse U-shaped relationship between top executive tenure and an organization's financial performance. Serfling (2012) found that the age of a CEO can have an important effect on corporate financial policy choices, firm performance, and the existence of agency costs within a firm. Thus, older CEOs tend to invest less than younger CEOs, and this finding is concentrated in firms with above median investment opportunities. These situation suggests that older CEOs may be passing up investing in valuable projects, and thereby, creating agency costs through underinvestment.

However, as regards the relationship between CEO characteristics, previous studies researched predominantly the relationship between CEO characteristics-firm performance-CEO turnover. In this study we will research the relationship between $\mathrm{CEO}$ characteristics and firm performance, but without considering the probability of $\mathrm{CEO}$ turnover. Also, previous studies which used CEO age and CEO tenure, analysed their impact on CEO 
compensation. Li \& Maksmovic (2010) stated that boards with short industry tenure negatively affect firm performance by selecting star CEOs who do not possess the necessary management skills.

\section{Hypotheses Development}

The global objective of our research consist in the examination of the relationship between corporate governance mechanisms, CEO characteristics and the performance of the U.S. listed companies.

We set the following hypotheses which will be tested afterwards, in accordance with the studies mentioned previously:

- Hypothesis $1\left(\mathrm{H}_{1}\right)$ : There is a positive relationship between the insider shareholdings and firm performance (Agrawal \& Knoeber, 1996);

- Hypothesis $2\left(\mathrm{H}_{2}\right)$ : There is a positive relationship between the number of the independent directors from the board of directors and firm performance (Baysinger \& Butler, 1985; Rosenstein \& Wyatt, 1990; Ezzamel \& Watson, 1993; Millstein \& MacAvoy, 1998; Brown \& Caylor, 2004; Bhagat \& Bolton, 2008);

- Hypothesis $3\left(\mathrm{H}_{3}\right)$ : There is a negative relationship between the size of the board of directors and firm performance (Yermack, 1996; Hermalin \& Weisbach, 2001; Beekes, Hong \& Owen, 2010);

- Hypothesis $4\left(\mathrm{H}_{4}\right)$ : There is a positive relationship between the institutional investors' and mutual funds' shareholdings and firm performance (McConnell \& Servaes, 1990);

- Hypothesis $5\left(\mathrm{H}_{5}\right)$ : The companies in which the CEO and the Chairman are different persons, are recording better performance relative to the companies in which the CEO and the Chairman are the same person (Jensen, 1993; Brickley et al., 1997; Belkhir, 2004; Bhagat \& Bolton, 2008);

- Hypothesis $6\left(\mathrm{H}_{6}\right)$ : The companies where the CEO is resident in the United States are recording lower performance relative to the companies where the CEO is not resident in the United States. Similar Sanda et al. (2005), to examine the extent to which business experience and skills of CEOs play an important role in affecting firm performance, we made a simplifying assumption that in U.S., compared with their local counterparts, foreign CEOs have more experience in modern management techniques and have greater international exposure;

- Hypothesis $7\left(\mathrm{H}_{7}\right)$ : The companies where the CEO is their founder are recording better performance relative to the companies where the CEO is not their founder (Villalonga \& Amit, 2006; Palia et al., 2008; Adams et al., 2009; Fahlenbrach, 2009);

- Hypothesis $8\left(\mathrm{H}_{8}\right)$ : There is a negative relationship between the age of the CEO and firm performance. When we designed this hypothesis, we considered the tournament model. Thus, a strand of the tournament literature has focused on rank-order tournaments, in which workers are paid according to their relative performance in identical tasks. However, we considered that there are younger employees than CEO which could perform better.

- Hypothesis $9\left(\mathrm{H}_{9}\right)$ : There is a positive relationship between the CEO tenure as Chief Executive Officer and firm performance. We consider that an increased tenure is accompanied by professional skills, which will be used in order to enhance the firm performance.

\section{Description of the Database and Research Methodology}

The process regarding the creation of the database, in order to investigate the relationship between corporate governance mechanisms, CEO characteristics and firm performance, consisted in using a random sample of 155 U.S companies, provided by Institutional Shareholder Services (ISS). However, this sample initially comprised only Governance Risk Indicators, which we used to research the relationship between corporate governance ratings and firm performance, in another study. After we got this sample, we started to collect data regarding corporate governance (both corporate governance mechanisms and CEO characteristics), data regarding firm performance and firm characteristics data (as firm size, firm age and gearing), from public sources. Also, all the data corresponds to the year 2011.

The companies from the sample belong to twenty different industries, including banking and financial services sector. Also, the companies have the following distribution regarding the industry membership: 55 companies listed at New York Stock Exchange, 94 companies listed at Nasdaq and 6 companies listed at American Stock Exchange. 
Table 1. Variables Covered in the Empirical Research

\begin{tabular}{|c|c|c|}
\hline Variable Name & Description of the variable & Data Source \\
\hline \multicolumn{3}{|c|}{ 1. Data regarding corporate governance } \\
\hline Insider_Share (\%) & $\begin{array}{l}\text { The shareholdings of the insiders (fraction of shares held by the insiders from the total } \\
\text { shares) }\end{array}$ & \multirow[t]{2}{*}{ www.morningstar.com } \\
\hline BoardSize & The number of members which compose the board of directors & \\
\hline No_IndependentDir & The number of the independent directors from the board of directors & www.reuters.com \\
\hline Concent (\%) & The fraction of the shares held by the institutional investors and mutual funds & finance.yahoo.com \\
\hline CEO_Resident & $\begin{array}{l}\text { Dummy Variable } \\
\text { If the } \mathrm{CEO} \text { is resident in the U.S.A. }=\mathbf{0} \\
\text { If the CEO is not resident in the U.S.A. }=\mathbf{1}\end{array}$ & $\begin{array}{l}\text { www.reuters.com } \\
\text { people.forbes.com }\end{array}$ \\
\hline CEO_Status & $\begin{array}{l}\text { Dummy Variable } \\
\text { If the CEO is the Chairman of the Board }=\mathbf{0} \\
\text { If the CEO is not the Chairman of the Board }=\mathbf{1}\end{array}$ & \multirow{2}{*}{ www.bloomberg.com } \\
\hline CEO_Founder & $\begin{array}{l}\text { Dummy Variable } \\
\text { If the } \mathrm{CEO} \text { is the founder of the company }=\mathbf{1} \\
\text { If the } \mathrm{CEO} \text { is not the founder of the company }=\mathbf{0}\end{array}$ & \\
\hline CEO_Age & The age of the Chief Executive Officer & \multirow{2}{*}{ markets.ft.com } \\
\hline CEO_Tenure & The tenure of Chief Executive Officer as CEO & \\
\hline \multicolumn{3}{|c|}{ 2. Data regarding firm performance } \\
\hline $\mathbf{Q}$ & $\begin{array}{l}\text { Tobin's Q, as the ratio between the market value and replacement value of the same } \\
\text { physical asset }\end{array}$ & uk.advfn.com/ \\
\hline PBV & Price to book value, as the ratio of the market value of equity to the book value of equity. & \multirow{4}{*}{ www.barchart.com } \\
\hline ROA (\%) & $\begin{array}{l}\text { Return on Assets shows how profitable a company is relative to its total assets. It is } \\
\text { calculated by dividing a company's annual earnings by its total assets, expressed as a } \\
\text { percentage. }\end{array}$ & \\
\hline ROE (\%) & $\begin{array}{l}\text { Return on Equity measures the rate of return on the ownership interest (shareholders' } \\
\text { equity) of the common stock owners. It measures a firm's efficiency at generating profits } \\
\text { from every unit of shareholders' equity (also known as net assets or assets minus } \\
\text { liabilities). ROE is equal to a fiscal year's net income (after preferred stock dividends but } \\
\text { before common stock dividends) divided by total equity (excluding preferred shares), } \\
\text { expressed as a percentage. }\end{array}$ & \\
\hline PER & $\begin{array}{l}\text { Price-earnings ratio tells us how many times the market price of a share is vis-a-vis its } \\
\text { earning. It is calculated as the ratio between the market price of the share and the earning } \\
\text { per share. }\end{array}$ & \\
\hline \multicolumn{3}{|c|}{ 3. Data regarding the firm size } \\
\hline LogAssets & Logarithm of Total Assets & uk.advfn.com/ \\
\hline \multicolumn{3}{|c|}{ 4. Data regarding the firm age } \\
\hline Years_Listing & The number of years of listing at a Stock Exchange & $\begin{array}{l}\text { www.nyse.com } \\
\text { www.nasdaq.com }\end{array}$ \\
\hline \multicolumn{3}{|c|}{ 5. Data regarding the gearing } \\
\hline Financial_leverage & Financial leverage (calculated as the ratio of total debt to equity) & uk.advfn.com \\
\hline
\end{tabular}

Source: Own processing.

In Table 1 we describe the variables which will be used in the empirical research, respectively data regarding corporate governance (including both corporate governance mechanisms and CEO characteristics), data regarding firm performance, data regarding the size of the companies, data regarding the firm age and data regarding gearing.

In order to examine the influence of corporate governance mechanisms and CEO characteristics on firm performance, in the literature on corporate governance, we have found the usage of the following type of models: multifactorial linear regression models, simultaneous equation models, as estimating through generalized method of moments. To test the hypoteses mentioned above we decided to use the cross-section multiple linear regression, following the general model, because our data correspond to one period, respectively, the year 2011:

$$
y_{i}=\alpha+\beta_{1} x_{1 i}+\beta_{2} x_{2 i}+\ldots+\beta_{m} x_{m i}+\varepsilon_{i}
$$


where:

$\mathrm{y}_{\mathrm{i}}=$ the dependent variable, represented by the firm performance;

$\alpha=$ this parameter is called the constant or intercept and represents the expected response when $x=0$. It quantify the influence of all determinants of firm performance with the exception of the independent variables introduced in the model (and which were not taken into consideration through an explanatory variable, but which are characterized through some stability in time);

$\beta=$ this parameter is called the slope, and represents the expected increment in the response per unit change in $\mathrm{x}$

$\mathrm{x}_{\mathrm{ji}}=$ the independent variable $\mathrm{j}$ for each company $\mathrm{i}$;

$\varepsilon_{\mathrm{i}}=$ the residual term of the regression, quantifying the influence of factors with random action (not systematically), characterized by the fact that the mean is zero and the variance is constant;

$\mathrm{i}=$ the company $=1,2, \ldots, 155$.

Table 2. The Variables from the Econometric Research

\begin{tabular}{|c|c|}
\hline Dependent Variables & Independent Variables \\
\hline \multirow{4}{*}{ The firm performance is revealed through the following variables: } & Insider_Share \\
\hline & BoardSize \\
\hline & No_IndependentDir \\
\hline & Concent \\
\hline \multirow{9}{*}{$\begin{array}{c}\text { Q } \\
\text { PBV } \\
\text { ROA } \\
\text { ROE } \\
\text { PER }\end{array}$} & CEO_Resident \\
\hline & CEO_Status \\
\hline & CEO_Founder \\
\hline & CEO_Age \\
\hline & CEO_Tenure \\
\hline & Control Variables \\
\hline & LogAssets \\
\hline & Years_Listing \\
\hline & Financial_leverage \\
\hline
\end{tabular}

Source: Own processing.

In Table 2 we present the variables from the econometric models which will be developed beyond, respectively the dependent variables (variables which quantify the firm performance), independent variables (variables which are showing the corporate governance mechanisms and CEO characteristics) and control variables (variables which measure the company size, company age and gearing).

Thus, the relationship between corporate governance mechanisms and U.S. listed companies' performance will be investigated through five econometric models. By taking into consideration the fact that the relationship between firm performance and corporate governance variables is not linear, we considered in the first four regression models the quadratic values of some variables. Besides, in order to remove the multicollinearity problem, which could determine the misrepresentation of the interpretations regarding the results from the models, we centered the values of the variables which followed to be squared.

In the corporate governance literature, we identified three main approaches to firm level performance: studies based on market prices, accounting ratios and total factor profitability. However, measuring firm performance using accounting ratios is also common in the corporate governance literature, in particular, return on assets and return on equity. The studies in which performance is measured through Tobin's Q and is operationalized as market to book are consistent with agency theory. Thus, large outside owners destroy market value, inside owners create it unless the stakes are unusually big and direct ownership is more beneficial than indirect (Bocean $\&$ Barbu, 2007). The return on assets and return on equity are accounting measures of profitability and efficiency. On the other hand, Tobin's Q, price to book value and price-earnings ratio capture market expectations about future earnings. While the ROA and ROE-corporate governance link reflects a tangible, balance-sheet effect, Tobin's Q, PBV and PER-corporate governance nexus has more to do with market perceptions about the value of corporate governance.

We used as control variables the logarithm of total assets, the number of years of listing at a Stock Exchange and 
the financial leverage. However, there is considerable evidence that the size of the firm plays an important role in corporate governance and corporate performance, and that there is a negative significant relationship, when it's used as a control variable, to measure the effect of corporate governance on firm value. The logarithm of total assets is used as a proxy for firm size (Al-Haddad, Alzurqan \& Al_Sufy, 2011). The leverage ratio can, on one hand, improve performance by limiting managerial misbehavior and by serving as a signal of high quality, but, on the other hand, high leverage may lead to asset substitution and underinvestment (Bebczuk, 2005). We also consider the firm age, as the number of years of listing at a Stock Exchange, instead of number of years from founding. Loderer \& Waelchli (2011) asserted the fact that as firms grow older, their performance deteriorates. Also they mentioned that ROA goes down, costs go up, and market size shrinks.

Like McConnell \& Servaes (1990) and Sanda et al. (2005), we followed the same approach and we designed five models to capture the impact of corporate governance mechanisms and CEO characteristics on firm performance.

The first model was designed to capture the impact of all corporate governance mechanisms, and the status of CEO regarding duality, on firm performance, without taking into consideration the control variables:

\section{- Model 1}

Firm_Performance $=\alpha+\beta_{1} *$ No_IndependentDir $+\beta_{2}{ }^{*}$ Insider_Share $+\beta_{3}{ }^{*}$ Insider_Share ${ }^{2}+\beta_{4}{ }^{*}$ BoardSize + $\beta_{5} *$ BoardSize $^{2}+\beta_{6} *$ CEO_Status $+\beta_{7} *$ Concent $+\varepsilon_{\mathrm{i}}$

In the second model we try to capture the impact of all corporate governance mechanisms, and the status of CEO regarding duality, on firm performance, but controlling for firm size and gearing:

\section{- Model 2}

Firm_Performance $=\alpha+\beta_{1} *$ No_IndependentDir $+\beta_{2}{ }^{*}$ Insider_Share $+\beta_{3}{ }^{*}$ Insider_Share ${ }^{2}+\beta_{4}{ }^{*}$ BoardSize + $\beta_{5} *$ BoardSize $^{2}+\beta_{6} *$ CEO_Status $+\beta_{7} *$ Concent $+\beta_{8} *$ Concent $^{2}+\bar{\beta}_{9} *$ LogAssets $+\beta_{10} *$ Financial_leverage $+\varepsilon_{i}$

The third model was designed to capture the impact of all corporate governance mechanisms, the status of CEO regarding duality and residence, on firm performance, without taking into consideration the control variables:

\section{- Model 3}

Firm_Performance $=\alpha+\beta_{1} *$ No_IndependentDir $+\beta_{2}{ }^{*}$ Insider_Share $+\beta_{3} *$ Insider_Share ${ }^{2}+\beta_{4}{ }^{*}$ BoardSize + $\beta_{5}{ }^{*}$ BoardSize $^{2}+\beta_{6}{ }^{*}$ CEO_Resident $+\beta_{7} *$ CEO_Status $+\beta_{8}{ }^{*}$ Concent $+\varepsilon_{i}$

The fourth model was designed to capture the impact of all corporate governance mechanisms, the status of CEO regarding duality, and the possibility of being the founder of the company, on firm performance, without taking into consideration the control variables:

\section{- Model 4}

Firm_Performance $=\alpha+\beta_{1}{ }^{*}$ No_IndependentDir $+\beta_{2}{ }^{*}$ Insider_Share $+\beta_{3}{ }^{*}$ Insider_Share ${ }^{2}+\beta_{4}{ }^{*}$ BoardSize + $\beta_{5} *$ BoardSize $^{2}+\beta_{6} *$ CEO_Founder $+\beta_{7} *$ CEO_Status $+\beta_{8} *$ Concent $+\varepsilon_{\mathrm{i}}$

The purpose of the fifth model is to capture the impact of CEO age and CEO tenure on firm performance, controlling for gearing and firm age:

\section{- Model 5}

Firm_Performance $=\alpha+\beta_{1}{ }^{*}$ CEO_Age $+\beta_{2}{ }^{*}$ CEO_Tenure $+\beta_{3}{ }^{*}$ LogAssets $+\beta_{4}{ }^{*}$ Financial_leverage + $\beta_{5} *$ Years_Listing $+\varepsilon_{\mathrm{i}}$

\section{Descriptive Statistics}

In Table 3 we show descriptive statistics of the variables. Thus, in case of CEO_Status, by taking into consideration the median value (Table 3: Median for CEO_Status =1), there results that CEOs are not the Chairmans of the boards of directors. However, we conclude a majority of CEO with residence in the United States (Table 3: Median for CEO_Resident $=0$ ). Also, by taking into consideration the median value, the CEOs from the sample are not the founders of the companies that they mange (Table 3: Median for CEO_Founder $=0$ ). We can see that board size is between four and fifteen members, the median value being eight, in accordance with Lipton \& Lorsch (1992) and Brown \& Caylor (2004).

In Table 4 we show the Pearson's Correlation Matrix for all variables as they enter the regression model. Each box contains two values: the value of the correlation coefficient and the probability.

The size of the board of directors is positively correlated with return on assets (Pearson's Correlation Coefficient $=.18$, Prob. $=.01)$. This fact could be explained by that the boards composed of a greater number of members 
determine a significant control and a better performance. Also, return on assets is positively correlated with the number of independent directors from the board (Pearson's Correlation Coefficient $=.15$, Prob. $=.05$ ) and with the fraction of shares held by the institutional investors and mutual funds (Pearson's Correlation Coefficient $=.38$, Prob. $=0$ ). We could say that the companies benefit from the presence of independent directors and institutional investors and mutual funds. As regards the correlation between CEO_Status and firm performance, respectively the correlation between the age of the CEO and firm performance, we conclude no significant associations. There resulted a negative correlation between CEO_Resident and return on equity (Pearson's Correlation Coefficient $=-.17$, Prob. $=.02$ ), while there resulted that CEO_Founder and firm performance are not significant correlated. Thus, we can say that CEO_Founder does not influence firm performance, measured through all ratios.

Table 3. Descriptive Statistics of the Variables

\begin{tabular}{lllllll}
\hline Variable & No. observations & Minimum & Maximum & Mean & Median & Std. Deviation \\
\hline Q & 155 & .02 & 17.56 & 1.78 & .87 & 2.48 \\
PBV & 155 & -17.1 & 28.7 & 3.23 & 1.89 & 4.73 \\
ROA & 155 & -.94 & .36 & -.03 & .01 & .18 \\
ROE & 155 & -10.68 & 3.57 & -.20 & .06 & 1.25 \\
PER & 155 & -325.4 & 908.33 & 20.40 & 12.38 & 87.76 \\
Insider_Share & 155 & 0 & 1 & .05 & .01 & .10 \\
BoardSize & 155 & 4 & 15 & 8.46 & 8 & 2.16 \\
No_IndependentDir & 155 & 0 & 10 & 4.57 & 5 & 2.72 \\
Concent & 155 & 0 & 1.28 & .66 & .72 & .28 \\
CEO_Resident & 155 & 0 & 1 & .17 & 0 & .38 \\
CEO_Status & 155 & 0 & 1 & .55 & 1 & .49 \\
CEO_Founder & 155 & 0 & 1 & .07 & 0 & .25 \\
CEO_Age & 155 & 34 & 75 & 54.56 & 54 & 7.77 \\
CEO_Tenure & 155 & 0 & 92 & 9.90 & 8 & 10.07 \\
Years_Listing & 155 & 0 & 84 & 13.66 & 11 & 12.94 \\
LogAssets & 155 & 2.97 & 11.9 & 6.62 & 6.51 & 1.62 \\
Financial_leverage & 155 & -11.8 & 47.4 & 4.25 & 2.1 & 6.99 \\
\hline
\end{tabular}

Source: Own calculations using IBM SPSS Statistics 19.

However, there resulted positive correlations between return on assets and the tenure of the CEO (Pearson's Correlation Coefficient $=.16$, Prob. $=.03$ ) and between price-earnings ratio and the tenure of CEO (Pearson's Correlation Coefficient $=.16$, Prob. $=.04$ ). This fact could reflect a positive influence of the tenure of the CEO on firm performance measured with ROA and PER. However, we can expect that as the CEO tenure in the Chief Executive Officer position increases, the firm performance, measured with ROA and PER, is better. The variable which measures the number of years of listing at a Stock Exchange is positively correlated with return on assets (Pearson's Correlation Coefficient $=.22$, Prob. $=.00$ ), fact which could signify an improvement of the performance measured with ROA, as the time since listing increases. This fact contradict Loderer \& Waelchli (2011) which mentioned that ROA goes down as firms grow older.

We find that financial leverage is negatively correlated with Tobin's Q (Pearson's Correlation Coefficient $=-.19$, Prob. $=.01$ ). This fact could indicate that firms with low anticipated growth opportunities (low Tobin's Q) experience negative relation between leverage and growth. However, Aivazian (2005) mentioned that leverage is negatively related to investment and that this negative effect is significantly stronger for firms with low growth opportunities than those with high growth opportunities. This provides support to agency theories of corporate leverage, and especially the theory that leverage has a disciplining role for firms with low growth opportunities. Also, Myers (1977) argued that leverage could have a negative effect on investment because of an agency problem between shareholders and bondholders. On the other hand, financial leverage is positively correlated with price to book value ratio (Pearson's Correlation Coefficient $=.42$, Prob. $=0$ ). 
Table 4. Pearson's Correlation Matrix for all variables as they enter the regression model

\begin{tabular}{|c|c|c|c|c|c|c|c|c|c|c|c|c|c|c|c|c|c|}
\hline & 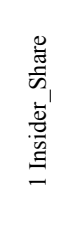 & 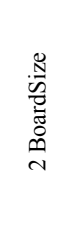 & 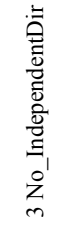 & $\begin{array}{l}\overrightarrow{\tilde{J}} \\
\ddot{\Xi} \\
\dot{\Xi} \\
\forall\end{array}$ & 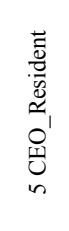 & 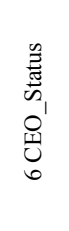 & 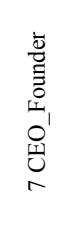 & 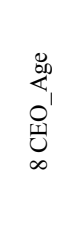 & 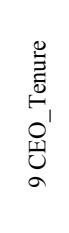 & 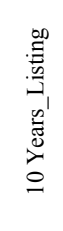 & $\begin{array}{l}0 \\
0 \\
0 \\
: 0 \\
0 \\
= \\
=\end{array}$ & $\begin{array}{l}\vec{m} \\
\stackrel{\vec{m}}{ } \\
\underline{I}\end{array}$ & $\begin{array}{l}\overleftarrow{0} \\
\stackrel{\sim}{n} \\
\underline{n}\end{array}$ & 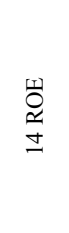 & 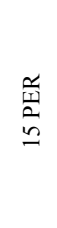 & 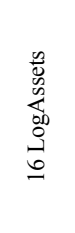 & 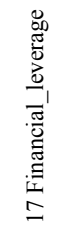 \\
\hline \multirow[t]{2}{*}{1} & 1 & $-.21^{* *}$ & $-.23^{* *}$ & $-.37^{* *}$ & .04 & -.12 & $.38^{* *}$ & -.02 & $.16^{*}$ & -.04 & .12 & .09 & -.10 & -.03 & .06 & $-.25^{* *}$ & .00 \\
\hline & & .00 & .00 & 0 & .57 & .13 & 0 & .72 & .03 & .56 & .12 & .23 & .17 & .69 & .41 & .00 & .94 \\
\hline \multirow[t]{2}{*}{2} & $-.21^{* *}$ & 1 & $.35^{* *}$ & .07 & -.15 & .02 & -.01 & .07 & .02 & $.23^{* *}$ & $-.23^{* *}$ & -.14 & $.18^{*}$ & .07 & -.04 & $.59^{* *}$ & .06 \\
\hline & .00 & & 0 & .35 & .05 & .73 & .87 & .38 & .73 & .00 & .00 & .07 & .01 & .38 & .55 & 0 & .42 \\
\hline \multirow[t]{2}{*}{3} & $-.23^{* *}$ & $.35^{* *}$ & 1 & $.23^{* *}$ & -.11 & -.08 & .07 & .04 & .09 & .11 & -.07 & .00 & $.15^{*}$ & .03 & .09 & $.29^{* *}$ & .02 \\
\hline & .00 & 0 & & .00 & .15 & .28 & .37 & .60 & .24 & .14 & .34 & .98 & .05 & .69 & .23 & 0 & .76 \\
\hline \multirow[t]{2}{*}{4} & $-.37^{* *}$ & .07 & $.23^{* *}$ & 1 & -.07 & -.00 & -.03 & .00 & .12 & .14 & $-.16^{*}$ & .06 & $.38^{* *}$ & .13 & .15 & $.28^{* *}$ & -.03 \\
\hline & 0 & .35 & .00 & & .33 & .96 & .66 & .92 & .11 & .06 & .04 & .43 & 0 & .09 & .06 & 0 & .64 \\
\hline \multirow[t]{2}{*}{5} & .04 & -.15 & -.11 & -.07 & 1 & .00 & .07 & -.04 & -.01 & -.11 & .03 & -.10 & -.02 & $-.17^{*}$ & -.05 & $-.17^{*}$ & -.09 \\
\hline & .57 & .05 & .15 & .33 & & .93 & .37 & .54 & .83 & .15 & .66 & .18 & .72 & .02 & .49 & .03 & .21 \\
\hline \multirow[t]{2}{*}{6} & -.12 & .02 & -.08 & -.00 & .00 & 1 & $-.20^{*}$ & $-.30^{* *}$ & -.14 & -.05 & -.03 & -.02 & -.06 & .06 & .03 & -.10 & .03 \\
\hline & .13 & .73 & .28 & .96 & .93 & & .01 & 0 & .07 & .48 & .70 & .79 & .44 & .44 & .71 & .20 & .64 \\
\hline \multirow[t]{2}{*}{7} & $.38^{* *}$ & -.01 & .07 & -.03 & .07 & $-.20^{*}$ & 1 & .03 & $.25^{* *}$ & -.07 & .01 & -.00 & .05 & -.01 & .07 & -.05 & 0 \\
\hline & 0 & .87 & .37 & .66 & .37 & .01 & & .66 & .00 & .38 & .81 & .92 & .52 & .87 & .35 & .48 & .99 \\
\hline \multirow[t]{2}{*}{8} & -.02 & .07 & .04 & .00 & -.04 & $-.30^{* *}$ & .03 & 1 & .12 & .02 & -.01 & .01 & .00 & -.03 & -.08 & $.16^{*}$ & .12 \\
\hline & .72 & .38 & .60 & .92 & .54 & 0 & .66 & & .11 & .72 & .87 & .89 & .98 & .66 & .29 & .04 & .12 \\
\hline \multirow[t]{2}{*}{9} & $.16^{*}$ & .02 & .09 & .12 & -.01 & -.14 & $.25^{* *}$ & .12 & 1 & .15 & -.07 & .00 & $.16^{*}$ & .07 & $.16^{*}$ & .04 & .04 \\
\hline & .03 & .73 & .24 & .11 & .83 & .07 & .00 & .11 & & .06 & .38 & .97 & .03 & .36 & .04 & .56 & .55 \\
\hline \multirow[t]{2}{*}{10} & -.04 & $.23^{* *}$ & .11 & .14 & -.11 & -.05 & -.07 & .02 & .15 & 1 & $-.19^{*}$ & -.13 & $.22^{* *}$ & .11 & -.01 & $.39^{* *}$ & .01 \\
\hline & .56 & .00 & .14 & .06 & .15 & .48 & .38 & .72 & .06 & & .01 & .10 & .00 & .15 & .85 & 0 & .85 \\
\hline \multirow[t]{2}{*}{11} & .12 & $-.23^{* *}$ & -.07 & $-.16^{*}$ & .03 & -.03 & .01 & -.01 & -.07 & $-.19^{*}$ & 1 & $.47^{* *}$ & $-.28^{* *}$ & .03 & -.08 & $-.46^{* *}$ & $-.19^{*}$ \\
\hline & .12 & .00 & .34 & .04 & .66 & .70 & .81 & .87 & .38 & .01 & & 0 & 0 & .65 & .30 & 0 & .01 \\
\hline \multirow[t]{2}{*}{12} & .09 & -.14 & .00 & .06 & -.10 & -.02 & -.00 & .01 & .00 & -.13 & $.47^{* *}$ & 1 & -.10 & .14 & -.00 & $-.23^{* *}$ & $.42^{* *}$ \\
\hline & .23 & .07 & .98 & .43 & .18 & .79 & .92 & .89 & .97 & .10 & 0 & & .20 & .07 & .94 & .00 & 0 \\
\hline \multirow[t]{2}{*}{13} & -.10 & $.18^{*}$ & $.15^{*}$ & $.38^{* *}$ & -.02 & -.06 & .05 & .00 & $.16^{*}$ & $.22^{* *}$ & $-.28^{* *}$ & -.10 & 1 & $.23^{* *}$ & .13 & $.37^{* *}$ & .03 \\
\hline & .17 & .01 & .05 & 0 & .72 & .44 & .52 & .98 & .03 & .00 & 0 & .20 & & .00 & .08 & 0 & .64 \\
\hline \multirow[t]{2}{*}{14} & -.03 & .07 & .03 & .13 & $-.17^{*}$ & .06 & -.01 & -.03 & .07 & .11 & .03 & .14 & $.23^{* *}$ & 1 & .03 & .04 & -.12 \\
\hline & .69 & .38 & .69 & .09 & .02 & .44 & .87 & .66 & .36 & .15 & .65 & .07 & .00 & & .7 & .61 & .13 \\
\hline \multirow[t]{2}{*}{15} & .06 & -.04 & .09 & .15 & -.05 & .03 & .07 & -.08 & $.16^{*}$ & -.01 & -.08 & -.00 & .13 & .03 & 1 & .10 & .02 \\
\hline & .41 & .55 & .23 & .06 & .49 & .71 & .35 & .29 & .04 & .85 & .30 & .94 & .08 & .7 & & .20 & .72 \\
\hline \multirow[t]{2}{*}{16} & $-.25^{* *}$ & $.59^{* *}$ & $.29^{* *}$ & $.28^{* *}$ & $-.17^{*}$ & -.10 & -.05 & $.16^{*}$ & .04 & $.39^{* *}$ & $-.46^{* *}$ & $-.23^{* *}$ & $.37^{* *}$ & .04 & .10 & 1 & .13 \\
\hline & .00 & 0 & 0 & 0 & .03 & .20 & .48 & .04 & .56 & 0 & 0 & .00 & 0 & .61 & .20 & & .08 \\
\hline \multirow[t]{2}{*}{17} & .00 & .06 & .02 & -.03 & -.09 & .03 & 0 & .12 & .04 & .01 & $-.19^{*}$ & $.42^{* *}$ & .03 & -.12 & .02 & .13 & 1 \\
\hline & .94 & .42 & .76 & .64 & .21 & .64 & .99 & .12 & .55 & .85 & .01 & 0 & .64 & .13 & .72 & .08 & \\
\hline
\end{tabular}

Note: **. Correlation is significant at the 0.01 level (2-tailed) *.Correlation is significant at the 0.05 level (2-tailed).

Source: Own calculations using IBM SPSS Statistics 19.

Also, there resulted positive correlations between the size of the companies and the size of the board of directors (Pearson's Correlation Coefficient $=.59$, Prob. $=0$ ), respectively between the size of the companies and the number of the independent directors from the board (Pearson's Correlation Coefficient $=.29$, Prob. $=0$ ). This fact could signify that larger companies are identified through a higher number of members in the board of directors and a higher number of independent directors. There resulted a negative correlation between the number of the independent directors from the board and the insider shareholdings (Pearson's Correlation Coefficient $=-.23$, Prob. $=.00)$, similarly Bhagat \& Bolton (2008) (Correlation Coefficient $=-.14)$. 


\section{Empirical Resultsand Discussion}

In Table 5 we show the coefficient estimates for Model 1 . When we used return on equity $(\mathrm{F}=0.77, \mathrm{Sig} .=.60)$ and price to book value ratio $(\mathrm{F}=1.27$, Sig.=.26), as dependent variables, we could not validate the model, by considering the results of F-test, reason for which we did not report the coefficient estimates for these.

Table 5. Coefficient estimates for Model 1

\begin{tabular}{|c|c|c|c|c|c|c|c|c|c|}
\hline \multirow[t]{2}{*}{$\begin{array}{l}\text { Dependent variables } \rightarrow \\
\text { Explanatory variables } \downarrow\end{array}$} & \multicolumn{3}{|c|}{$\mathbf{Q}$} & \multicolumn{3}{|c|}{ ROA } & \multicolumn{3}{|c|}{ PER } \\
\hline & $\beta$ & $\mathrm{t}$ & Sig. & $\beta$ & $\mathrm{t}$ & Sig. & $\beta$ & $\mathrm{t}$ & Sig. \\
\hline (Constant) & 2.63 & 3.66 & $.00 * * *$ & -.20 & -4.10 & $.00 * * *$ & -53.87 & -2.10 & $.03 *$ \\
\hline No_IndependentDir & .03 & .40 & .68 & .00 & .19 & .84 & 3.98 & 1.39 & .16 \\
\hline Insider_Share & 6.33 & 1.60 & .11 & .29 & 1.06 & .28 & 277.32 & 1.96 & $.05 \dagger$ \\
\hline Insider_Share $^{2}$ & -8.89 & -1.67 & $.09 \dagger$ & -.26 & -.72 & .47 & -233.44 & -1.23 & .22 \\
\hline BoardSize & -.20 & -1.91 & $.05 \dagger$ & .01 & 1.89 & $.06 \dagger$ & -3.53 & -.91 & .36 \\
\hline BoardSize $^{2}$ & -.01 & -.52 & .60 & .00 & .44 & .65 & 1.33 & 1.18 & .24 \\
\hline CEO_Status & -.08 & -.22 & .82 & -.02 & -.70 & .48 & 11.68 & .82 & .41 \\
\hline Concent & -1.15 & -1.48 & .14 & .26 & 4.91 & $.00 * * *$ & 69.51 & 2.5 & $.01 *$ \\
\hline R Square & & .09 & & & .18 & & & .07 & \\
\hline Adjusted R Square & & .05 & & & .14 & & & .03 & \\
\hline F Sig. & & $2.22 .03^{*}$ & & & 4.82 .00 & & & $1.71 .10 \dagger$ & \\
\hline
\end{tabular}

Statistical significance: $\dagger \mathrm{p}<.10 ; * \mathrm{p}<.05 ; * * \mathrm{p}<.01 ; * * * \mathrm{p}<.001$.

Source: Own calculations using IBM SPSS Statistics 19.

Thus, from Model 1 results that between the number of the independent directors from the board and firm performance is not a statistically significant relationship. This fact is similar Bhagat \& Black (2000) and Hermalin \& Weisbach (2001), which used Tobin's Q as performance measure, to reflect the "added value" of some intangible factors, as corporate governance, but without identifying a relationship between the number of the independent directors and firm performance. Also, the lack of association between board structure and firm performance was acknowledged by Klein (1998), Demsetz \& Villalonga (2001), Weir \& Laing (2001), and Brown \& Caylor (2004).

When we used return on assets as dependent variable, in Model 1, there not resulted a statistically significant relationship between firm performance and the insider shareholdings (Model 1: $\beta=.29, p>.10$ ). This fact is similar Demsetz \& Lehn (1985) which found that ownership concentration and firm performance, represented through return on assets, are unrelated.

However for price-earnings ratio, a one percent increase of insider shareholdings, cause, in average, a 277.32 units increase of PER (Model 1: $\beta=277.32, p<.10$ ). For the Tobin's $Q$ rate, if we consider a statistical significance of $11 \%$, there would result a positive association between Tobin's $Q$ and the insider shareholdings (Model 1: $\beta=6.33, p=.11$ ). The relationship between Tobin's $Q$ and the insider shareholdings sustain the fact, very wide debated in corporate governance literature, that corporate governance is an endogenous variable and that there is a reverse causality mechanism between corporate governance quality and firm performance. Besides, the relationship between Tobin's Q and the insider shareholdings remains positive until a threshold, fact which could be observed through the negative coefficient estimate of the quadratic term of the insider shareholdings (Model 1: $\beta=-8.89, p<.10$ ). Beyond that threshold, the relationship becomes negative. Taking partial derivatives and solving for optimal values gave results suggesting an optimal value of $35.58 \%$ of the insider shareholdings (Note 1). Beyond this level a negative relationship is predicted to set in.

Hypothesis $1\left(\mathrm{H}_{1}\right)$, which stated a positive relationship between the insider shareholdings and firm performance is accepted, but only for Tobin's Q (until a threshold of $35.58 \%$ of the insider shareholdings) and for price-earnings ratio. Hypothesis $2\left(\mathrm{H}_{2}\right)$, which established a positive relationship between the number of the independent directors from the board of directors and firm performance is rejected, because we could not identify valid coefficient estimates using t-test.

The size of the board of directors is negatively associated with Tobin's Q (Model 1: $\beta=-.20, p<.10$ ) and positively associated with return on assets (Model 1: $\beta=.01, \mathrm{p}<.10$ ). The inverse relationship between the size of the board of directors and Tobin's Q is similar Yermack (1996) which identified, in average, that a unit increse of the log of board size, cause, a decrease of .428 units of Tobin's Q. Also, the inverse relationship 
between firm performance and the size of the board is supported by Hermalin \& Weisbach (2001), which used Tobin's Q as a performance measure. The positive relationship between the size of the board of directors and ROA is opposite Larcker, Richardson \& Tuna (2007) which identified a negative relationship. Thus, the Hypothesis $3\left(\mathrm{H}_{3}\right)$ of a negative relationship between the size of the board of directors and firm performance is accepted only for Tobin's Q.

By following the relationship between the status of the Chief Executive Officer, which could be also the Chairman of the board of directors, and firm performance, we did not find any statistically significant relationship. Thus, the Hypothesis $5\left(\mathrm{H}_{5}\right)$, which stated that the companies in which the CEO and the Chairman are different persons, are recording better performance relative to the companies in which the CEO and the Chairman are the same person is rejected. Our result is similar Daily \& Dalton (1992) and Chen et al. (2008). However, our result is opposite Bhagat and Bolton (2008), which supported that the separation between the CEO and the Chairman is positively correlated with current and future operational performance. Also, our result is contrary Jensen (1993), Brickley et al. (1997) and Belkhir (2004).

Additionally, from the first model, we find that the fraction of the shares held by the institutional investors and mutual funds is positively associated with return on assets (Model $1: \beta=.26, p<.001$ ) and price-earnings ratio (Model 1: $\beta=69.51, \mathrm{p}<.05$ ).

Table 6. Coefficient estimates for Model 2

\begin{tabular}{|c|c|c|c|c|c|c|c|c|c|}
\hline \multirow[t]{2}{*}{$\begin{array}{l}\text { Dependent variables } \rightarrow \\
\text { Explanatory variables } \downarrow\end{array}$} & \multicolumn{3}{|c|}{$\mathbf{Q}$} & \multicolumn{3}{|c|}{ PBV } & \multicolumn{3}{|c|}{ ROA } \\
\hline & $\beta$ & $\mathrm{t}$ & Sig. & $\beta$ & $\mathrm{t}$ & Sig. & $\beta$ & $\mathrm{t}$ & Sig. \\
\hline (Constant) & 6.42 & 5.80 & $.00 * * *$ & 8.11 & 3.97 & $.00 * * *$ & -0.20 & -2.435 & $.016^{*}$ \\
\hline No_IndependentDir & .04 & .64 & .52 & .09 & .74 & .45 & .00 & .09 & .92 \\
\hline Insider_Share & 5.23 & 1.46 & .14 & 9.58 & 1.45 & .14 & .37 & 1.38 & .16 \\
\hline Insider_Share $^{2}$ & -9.70 & -2.00 & $.04 *$ & -11.39 & -1.27 & .20 & -.22 & -.61 & .53 \\
\hline BoardSize & .08 & .76 & .44 & .06 & .33 & .74 & .00 & .24 & .80 \\
\hline BoardSize $^{2}$ & .01 & .54 & .58 & .05 & 1.02 & .30 & -.00 & -.28 & .77 \\
\hline CEO_Status & -.27 & -.77 & .44 & -.46 & -.69 & .49 & -.01 & -.44 & .65 \\
\hline Concent & .21 & .28 & .77 & 4.49 & 3.26 & $.00 * *$ & .19 & 3.45 & $.00 * *$ \\
\hline Concent $^{2}$ & 4.74 & 2.15 & $.03 *$ & 7.64 & 1.88 & $.06 \dagger$ & -.36 & -2.19 & 0.03* \\
\hline LogAssets & -.73 & -4.92 & $.00 * * *$ & -1.09 & -3.97 & $.00 * * *$ & .03 & 2.83 & $.00 * *$ \\
\hline Financial_leverage & -.04 & -1.72 & $.08 \dagger$ & .33 & 7.00 & $.00 * * *$ & .00 & -.20 & .84 \\
\hline R Square & \multicolumn{3}{|c|}{.28} & \multicolumn{3}{|c|}{.33} & \multicolumn{3}{|c|}{.26} \\
\hline Adjusted R Square & \multicolumn{3}{|c|}{.23} & \multicolumn{3}{|c|}{.28} & \multicolumn{3}{|c|}{.20} \\
\hline F Sig. & \multicolumn{3}{|c|}{$5.83 .00 * * *$} & \multicolumn{3}{|c|}{$7.22 .00 * * *$} & \multicolumn{3}{|c|}{$5.06 .00 * * *$} \\
\hline
\end{tabular}

Statistical significance: $\uparrow \mathrm{p}<.10 ; * \mathrm{p}<.05 ; * * \mathrm{p}<.01 ; * * * \mathrm{p}<.001$.

Source: Own calculations using IBM SPSS Statistics 19.

In Table 6 we show the coefficient estimates for Model 2. Also, we could not validate the model when we used return on equity $(\mathrm{F}=.77$, Sig.=.65) and price-earnings ratio $(\mathrm{F}=1.48$, Sig.=.15) as dependent variables, reason for which we did not report the results.

In Model 2, by controlling for the size of the companies and for gearing, the statistically significant relationships, between the insider shareholdings and firm performance and between the size of the board of directors and firm performance disappeared. There resulted a lack of association between the fraction of the shares held by the institutional investors and mutual funds. This fact is supported also by Demsetz \& Villalonga (2001), which have not established a significant relationship between Tobin's Q rate and the fraction of the shares owned by the five largest shareholders. A positive relationship was recorded between the quadratic term of Concent and Tobin's $Q$ (Model 2: $\beta=4.74, p<.05$ ). A one percent increse of the fraction of shares held by the institutional investors and mutual funds, cause, in average, a 4.49 increase of the price to book value ratio (Model 2: $\beta=4.49, p<.01$ ). According to Berle \& Means (1932), there must be a concentrated ownership in order to record better performance. However, in the United States of America is a dispersed ownership.

For return on assets, a one percent increse of the fraction of shares held by the institutional investors and mutual funds, cause, in average, a 19\% increase of ROA (Model 2: $\beta=.19, \mathrm{p}<.01$ ). Similar to the first model, taking partial derivatives and solving for optimal values gave results suggesting an optimal value of $26.02 \%$ of the 
institutional investors and mutual funds shareholdings (Note 2). Beyond this level a negative relationship is predicted to set in. The Hypothesis $4\left(\mathrm{H}_{4}\right)$, of a positive relationship between the institutional investors' and mutual funds' shareholdings and firm performance is validated only for the price to book value ratio and return on assets (but until a threshold of $26.02 \%$ of the shares held by the institutional investors and mutual funds).

Table 7. Coefficient estimates for Model 3

\begin{tabular}{|c|c|c|c|c|c|c|}
\hline \multirow[t]{2}{*}{$\begin{array}{l}\text { Dependent variables } \rightarrow \\
\text { Explanatory variables } \downarrow\end{array}$} & \multicolumn{3}{|c|}{$\mathbf{Q}$} & \multicolumn{3}{|c|}{ ROA } \\
\hline & $\beta$ & $\mathrm{t}$ & Sig. & $\beta$ & $\mathrm{t}$ & Sig. \\
\hline (Constant) & 2.66 & 3.62 & $.00 * * *$ & -.21 & -4.08 & $.00 * * *$ \\
\hline No_IndependentDir & .03 & .38 & .70 & .00 & .21 & .83 \\
\hline Insider_Share & 6.37 & 1.60 & .11 & .29 & 1.04 & .29 \\
\hline Insider_Share $^{2}$ & -8.96 & -1.68 & $.09 \dagger$ & -.26 & -.69 & .48 \\
\hline BoardSize & -.21 & -1.92 & $.05 \dagger$ & .01 & 1.91 & $.05 \dagger$ \\
\hline BoardSize $^{2}$ & -.01 & -.52 & .59 & .00 & .46 & .64 \\
\hline CEO_Resident & -.11 & -.21 & .82 & .01 & .35 & .72 \\
\hline CEO_Status & -.08 & -.21 & .82 & -.02 & -.70 & .48 \\
\hline Concent & -1.16 & -1.48 & .13 & .27 & 4.91 & $.00 * * *$ \\
\hline R Square & \multicolumn{3}{|c|}{.09} & \multicolumn{3}{|c|}{.18} \\
\hline Adjusted R Square & \multicolumn{3}{|c|}{.04} & \multicolumn{3}{|c|}{.14} \\
\hline F Sig. & \multicolumn{3}{|c|}{$1.94 .05^{* *}$} & \multicolumn{3}{|c|}{$4.20 .00 * * *$} \\
\hline
\end{tabular}

Source: Own calculations using IBM SPSS Statistics 19.

In Table 7, we report the coefficient estimates for Model 3. From the F-test point of view, Model 3 is validated only when we used Tobin's Q and ROA as dependent variables. For price to book value, return on equity and price earnings ratio, the model was not validated, reason for which we did not report the coefficient estimates for these.

Thus, we did not find and statistically significant relationship between the residence of the Chief Executive Officer and firm performance. By considering this fact, we reject the Hypothesis $6\left(\mathrm{H}_{6}\right)$ and we mention that there is no difference regarding performance between the companies where CEO is resident in the United States and the companies where CEO is not resident in the United States. Additionally, it is confirmed the negative relationship between the size of the board of directors and Tobin's Q (Model 3: $\beta=-.21, p<.10$ ), respectively, the positive relationship between the size of the board of directors and return on assets (Model 3: $\beta=.01, p<.10$ ) Similar with Model 1 and Model 2, there resulted a positive association between the fraction of the shares held by the institutional investors and mutual funds and ROA (Model 3: $\beta=.27, \mathrm{p}<.01$ ).

Table 8. Coefficient estimates for Model 4

\begin{tabular}{|c|c|c|c|c|c|c|}
\hline $\begin{array}{l}\text { Dependent variables } \rightarrow \\
\text { Explanatory variables } \downarrow\end{array}$ & & $\mathbf{Q}$ & & & ROA & \\
\hline & $\beta$ & $\mathrm{t}$ & Sig. & $\beta$ & $\mathrm{t}$ & Sig. \\
\hline (Constant) & 2.64 & 3.66 & $.00 * * *$ & -.20 & -4.12 & $.00 * * *$ \\
\hline No_IndependentDir & .03 & .42 & .67 & .00 & .13 & .89 \\
\hline Insider_Share & 6.52 & 1.59 & .11 & .26 & .91 & .36 \\
\hline Insider_Share $^{2}$ & -8.91 & -1.67 & $.09 \dagger$ & -.26 & -.70 & .48 \\
\hline BoardSize & -.20 & -1.88 & $.06 \dagger$ & .01 & 1.83 & $.06 \dagger$ \\
\hline BoardSize $^{2}$ & -.01 & -.54 & .58 & .00 & .52 & .60 \\
\hline CEO_Founder & -.16 & -.19 & .84 & .03 & .49 & .62 \\
\hline CEO_Status & -.10 & -.24 & .80 & -.01 & -.61 & .54 \\
\hline Concent & -1.14 & -1.46 & .14 & .26 & 4.86 & $.00^{* * *}$ \\
\hline R Square & & .09 & & & .18 & \\
\hline Adjusted R Square & & .04 & & & .14 & \\
\hline F Sig. & & $1.94 .05 \dagger$ & & & $4.22 .00 * * *$ & \\
\hline
\end{tabular}

Source: Own calculations using IBM SPSS Statistics 19. 
In Table 8 we show the coefficient estimates for Model 4. Considering the F-test, we could not validate this model when we used as dependent variables price to book value, return on equity and price earnings ratio, reason for which we did not report the coefficient estimates for these.

Similar to the Hypothesis $6\left(\mathrm{H}_{6}\right)$, the Hypothesis $7\left(\mathrm{H}_{7}\right)$ is rejected. We found that there is no difference between the companies where CEO is their founder and the companies where CEO is not their founder. There is not a statistically significant relationship between the CEO_Founder and Tobin's Q or between CEO_Founder and ROA. Our result is contrary to Villalonga \& Amit (2006), Palia et al. (2008), Adams et al. (2009), and Fahlenbrach (2009). On the other hand, are confirmed the relationships between the size of the board of directors and Tobin's Q (Model 4: $\beta=-.20, p<.10$ ), respectively between the size of the board of directors and ROA (Model 4: $\beta=.01, \mathrm{p}<.10$ ). In fact, it is validated the positive relationship between Concent and ROA (Model 4: $\beta=.26, \mathrm{p}<.001)$.

Table 9. Coefficient estimates for Model 5

\begin{tabular}{|c|c|c|c|c|c|c|c|c|c|c|c|c|}
\hline $\begin{array}{l}\text { Dependent variables } \rightarrow \\
\text { Explanatory variables } \downarrow\end{array}$ & \multicolumn{3}{|c|}{$\mathbf{Q}$} & \multicolumn{3}{|c|}{ PBV } & \multicolumn{3}{|c|}{ ROA } & \multicolumn{3}{|c|}{ PER } \\
\hline \multirow[b]{2}{*}{ (Constant) } & $\beta$ & $\mathrm{t}$ & Sig. & $\beta$ & $\mathrm{t}$ & Sig. & $\beta$ & $\mathrm{t}$ & Sig. & $\beta$ & $\mathrm{t}$ & Sig. \\
\hline & 5.29 & 3.87 & $.00 * * *$ & 7.51 & 2.92 & $.00 * *$ & -.24 & -2.26 & $.02 *$ & 38.92 & .72 & .47 \\
\hline CEO_Age & .02 & 1.17 & .24 & .00 & .01 & .98 & -.00 & -.98 & .32 & -1.48 & -1.61 & $.10 \dagger$ \\
\hline CEO_Tenure & -.01 & -.71 & .47 & -.00 & -.03 & .97 & .003 & 1.98 & $.04 *$ & 1.63 & 2.31 & $.02 * *$ \\
\hline LogAssets & -.70 & -5.79 & $.00 * * *$ & -.83 & -3.64 & $.00 * * *$ & .04 & 4.26 & $.00 * * *$ & 8.24 & 1.72 & $.08 \dagger$ \\
\hline Financial_leverage & -.04 & -1.90 & $.05 \dagger$ & .31 & 6.47 & $.00 * * *$ & .00 & -.14 & .88 & .19 & .19 & .84 \\
\hline Years_Listing & -.00 & -.06 & .95 & -.00 & -.32 & .74 & .00 & .74 & .45 & -.67 & -1.13 & .25 \\
\hline R Square & \multicolumn{3}{|c|}{.24} & \multicolumn{3}{|c|}{.26} & \multicolumn{3}{|c|}{.17} & \multicolumn{3}{|c|}{.05} \\
\hline Adjusted R Square & \multicolumn{3}{|c|}{.22} & \multicolumn{3}{|c|}{.24} & \multicolumn{3}{|c|}{.14} & \multicolumn{3}{|c|}{.02} \\
\hline F Sig. & \multicolumn{3}{|c|}{$9.67 .00^{* * *}$} & \multicolumn{3}{|c|}{$10.71 .00 * * *$} & \multicolumn{3}{|c|}{$6.10 .00 * * *$} & \multicolumn{3}{|c|}{$1.87 .10 \dagger$} \\
\hline
\end{tabular}

Statistical significance: $\dagger \mathrm{p}<.10 ; * \mathrm{p}<.05 ; * * \mathrm{p}<.01 ; * * * \mathrm{p}<.001$.

Source: Own calculations using IBM SPSS Statistics 19.

In Table 9 we report the coefficient estimates for Model 5. Considering the F-test we could not validate the model when we used return on equity as dependent variable, reason for which we didn't report the result for it.

The Hypothesis $8\left(\mathrm{H}_{8}\right)$, that stated a negative relationship between the age of the CEO and firm performance, is accepted only for PER (Model 5: $\beta=-1.48, \mathrm{p}<.10$ ). For the other measures of firm performance we could not identify a statistically significant relationship between firm performance and the age of the CEO. Thus, for Q, ROA, ROE and PBV, our result is close to Nelson (2005), who found no relationship between CEO age, tenure or compensation and governance changes

However, contrary Loderer \& Waelchli (2011), we find that the period of time since the company was listed at a Stock Exchange has no influence on firm performance.

The Hypothesis $9\left(\mathrm{H}_{9}\right)$, of a positive relationship between the CEO tenure as Chief Executive Officer and firm performance, is accepted only for ROA (Model 5: $\beta=.003, \mathrm{p}<.05$ ) and for price-earnings ratio (Model 5: $\beta=$ $1.63, \mathrm{p}<.01)$. Thus, the tenure of the CEO is positively associated with firm performance, as measured by ROA and PER. Similar Model 2, we find the negative relationship between the financial leverage and Tobin's Q (Model 5: $\beta=-.04, p<.10$ ) and the positive relationship between the financial leverage and PBV (Model 5: $\beta=.31, \mathrm{p}<.001)$. When we used the return on equity as dependent variable, we could not validate the model $(\mathrm{F}=1.03$, Sig. $=.40)$. However, we could not find a statistically significant relationship between the number of years of listing at a Stock Exchange and firm performance.

\section{Summary and Conclusions}

The aim of this research was to investigate the impact of corporate governance mechanisms and CEO characteristics on a random sample of 155 U.S. listed companies' performance, considering five proxy measures for performance (Tobin's Q, PBV, ROA, ROE and PER), four corporate governance mechanisms (shareholdings of insiders, shareholdings of institutional investors and mutual funds, board size and the number of independent directors) and five proxy measures for CEO characteristics (CEO_Resident, CEO_Status, CEO_Founder, CEO_Age and CEO_Tenure). Thus, there resulted a positive relationship between insider shareholdings and price-earnings ratio, respectively Tobin's Q (for Tobin's Q until a threshold of $35.58 \%$ of the shares held by the insiders, beyond the relationship becomes negative). As regarding the relationship between the number of independent directors from the board and firm performance, there resulted no significant relationship. 
Similar to previous studies, we got mixed results regarding the relationship between the size of the board of directors and firm performance. Thus, there resulted a negative relationship between the size of the board of directors and Tobin's Q, but a positive relationship between the size of the board and return on assets. Also we concluded a positive relationship between the shareholdings of the institutional investors and mutual funds and return on assets, but until a threshold of $26.02 \%$ of the shares held by institutional investors and mutual funds, beyond the relationship becomes negative. However, there resulted a positive relationship between the shareholdings of the institutional investors and mutual funds and price to book value ratio.

From the CEO point of view, there resulted the fact that there is not any relationship regarding firm performance between the companies where the CEO and Chairman are the same person and the companies where the CEO and Chairman are different persons. Additionally, as regards the residence of the CEOs and their possibility to found the companies that they mange, we concluded no influence on company performance. We found a negative relationship between the age of the CEO and PER, while there resulted a positive relationship between the tenure of the CEO and ROA and between the tenure of the CEO and PER.

As future research, we mention the investigation of the relationship between corporate governance mechanisms, CEO characteristics and firm performance, using another econometric approaches, as estimating through simultaneous equations models or through the generalized method of moments. Also the relationship could be modelled via neural networks or fuzzy logic analysis. However, we could overtake corporate governance by a global index which could be built through principal component analysis. On the other hand, the influence of corporate governance on U.S. listed companies' performance could be investigated by expanding the sample and the analysis period.

\section{References}

Adams, R., Almeida, H., \& Ferreira, D. (2009). Understanding the relationship between founder-CEOs and firm $\begin{array}{lllll}\text { performance. Journal of } & \text { Empirical }\end{array}$ http://dx.doi.org/10.1016/j.jempfin.2008.05.002

Agrawal, A., \& Knoeber, C. (1996). Firm performance and mechanisms to control agency problems between managers and shareholders. Journal of Financial and Quantitative Analysis, 3(31), 377-397.

Aivazian, V., Ge, Y., \& Qiu, J. (2005). The impact of leverage on firm investment: Canadian evidence. Journal of Corporate Finance, 11(1-2), 277-291. http://dx.doi.org/10.1016/S0929-1199(03)00062-2

Al-Haddad, W., Alzurqan, S. T., \& Al_Sufy, F. J. (2011). The Effect of Corporate Governance on the Performance of Jordanian Industrial Companies: An empirical study on Amman Stock Exchange. International Journal of Humanities and Social Science, 1(4), 55-69.

Baysinger, B. D., \& Butler, H. N. (1985). Corporate governance and board of directors performance effects of changes in board composition. Journal of Law Economics and Organization, 1(1), 101-124.

Bebczuk, R. (2005). Corporate Governance and Ownership: Measurement and Impact on Corporate Performance and Dividend Policies in Argentina. Center for Financial Stability and Universidad Nacional de La Plata, Research Network Working papers, R-516.

Beekes, W., Hong, A., \& Owen, S. (2010). An Alternative Measure of Corporate Governance using Discrete Principal Component Analysis. Working Paper, 19.

Belkhir, M. (2004). Board Structure, Ownership Structure, and Firm Performance: Evidence from Banking. Applied Financial Economics, 19(19), 1581-1593.

Berle, A., \& Means, G. (1932). The Modern Corporation and Private Property. Macmillan, New York, 13.

Bhagat, S., \& Black, B. (2000). Board independence and long-term firm performance. Stanford Law School Working Paper, No. 188, 17.

Bhagat, S., \& Bolton, B. (2008). Corporate governance and firm performance. Journal of Corporate Finance, 14(3), 257-273. http://dx.doi.org/10.1016/j.jcorpfin.2008.03.006

Bocean, C., \& Barbu, C. (2007). Corporate governance and firm performance. Management \& Marketing, 5(1), 125-131.

Brickley, J. A., Coles, J. L., \& Jarrell, G. (1997). Leadership structure: Separating the CEO and Chairman of the Board. Journal of Corporate Finance, 3(3), 189-220. http://dx.doi.org/10.1016/S0929-1199(96)00013-2

Brown, L., \& Caylor, M. (2004). Corporate governance and firm performance. Georgia State University, Working Paper, 6-7. 
Chaganti, R., \& Damanpour, F. (1991). Institutional ownership, capital structure and firm performance. Strategic Management Journal, 12(7), 479-491. http://dx.doi.org/10.1002/smj.4250120702

Chen, C. W., Lin, J. B., \& Yi, B. (2008). CEO duality and firm performance-an endogenous issue. Corporate Ownership \& Control, 6(1), 58-65.

Core, J., \& Larcker, D. (2002). Performance consequences of mandatory increases in executive stock ownership. The Wharton School, University of Pennsylvania, Philadelphia, 1-36.

Core, J., Holthausen, R., \& Larcker, D. (1999). Corporate governance, Chief Executive Officer compensation, and firm performance. Journal of Financial Economics, 51(3), 371-406. http://dx.doi.org/10.1016/S0304-405X(98)00058-0

Daily, C., \& Dalton, D. (1992). The relationship between governance structure and corporate performance in entrepreneurial firms. Journal of Business Venturing, 7(5), 375-386. http://dx.doi.org/10.1016/0883-9026(92)90014-I

Demsetz, H. (1983). The Structure of Ownership and the Theory of the Firm. The Journal of Law and Economics, 26(2), 375-390.

Demsetz, H., \& Lehn, K. (1985). The Structure of Corporate Ownership: Causes and Consequences. Journal of Political Economy, 93(6), 1174.

Demsetz, H., \& Villalonga, B. (2001). Ownership structure and corporate performance. Journal of Corporate Finance, 7(3), 211. http://dx.doi.org/10.1016/S0929-1199(01)00020-7

Eisenberg, T., Sundgren, S., \& Wells, M. T. (1998). Larger board size and decreasing firm value in small firms. Journal of Financial Economics, 48(1), 35-54. http://dx.doi.org/10.1016/S0304-405X(98)00003-8

Ezzamel, M. A., \& Watson, R. (1993). Organizational Form, Ownership Structure and Corporate Performance: A Conceptual Empirical Analysis of U.K. Companies. British Journal of Management, 4(3), 161-176.

Fahlenbrach, R. (2009). Founder-CEOs, Investment Decisions, and Stock Market Performance. Journal of Financial and Quantitative Analysis, 44(2), 439-466. http://dx.doi.org/10.1017/S0022109009090139

Fama, E. (1980). Agency problems and the theory of the firm. Journal of Political Economy, 88(2), 289.

Fama, E., \& Jensen, M. (1983). Separation of Ownership and Control. Journal of Law and Economics, 26(2), 311.

Hermalin, B., \& Weisbach, M. (1991). The Effects of Board Composition and Direct Incentives on Firm Performance. Financial Management, 20(4), 101-112.

Hermalin, B., \& Weisbach, M. (2001). Boards of directors as an endogenously determined institution: a survey of the economic literature. National Bureau of Economic Research, Working Paper 8161, Cambridge, 391.

Holderness, C. G., Kroszner, R. S., \& Sheehan., D. P. (1999). Were the Good Old Days That Good? Changes in Managerial Stock Ownership Since the Great Depression. Journal of Finance, 54(2), 435-469.

Itturalde, D. T., Maseda, D. A., \& Arosa, D. B. (2011). Insiders Ownership and Firm Performance. Empirical Evidence. International Research Journal of Finance and Economics, 67, 120.

Jensen, M. C. (1993). The modern industrial revolution, Exit, and the failure of internal control systems. The Journal of Finance, 48(3), 831-880.

Jensen, M. C., \& Meckling, W. H. (1976). Theory of the firm: Managerial behaviour, agency costs and ownership structure. Journal of Financial Economics, 3(4), 305-360. http://dx.doi.org/10.1016/0304-405X(76)90026-X

John, C., \& Senbet, L. (1997). Corporate governance and board effectiveness. Departament of Finance, Working Paper Series 1998, FIN-98-045, 22.

Klein, A. (1998). Firm Performance and Board Committee Structure. Journal of Law and Economics, 41(1), 275-303.

Larcker, D., Richardson, S., \& Tuna, I. (2007). Corporate Governance, Accounting Outcomes, and Organizational Performance. The Accounting Review, 82(4), 963-1008.

Li, M., \& Maksimovic, V. (2010). Selection of star CEOs and its implications on firm performance and CEO compensation. Dissertation, University of Maryland.

Lipton, M., \& Lorsch, J. W. (1992). A Modest Proposal for Improved Corporate Governance. Business Lawyer, 
48(1), 59-67.

Loderer, C., \& Waelchli, U. (2011). Firm age and governance. University of Bern, Working Paper Series.

Lowenstein, L. (1991). Why managers should (and should not) have respect for their shareholders. Journal of Corporation Law, 17(1), 1-27.

Mashayekhi, B., \& Bazaz, M. S. (2008). Corporate Governance and Firm Performance in Iran. Journal of Contemporary Accounting \& Economics, 4(2), 156-172. http://dx.doi.org/10.1016/S1815-5669(10)70033-3

McConnell, J., \& Servaes, H. (1990). Additional evidence on equity ownership and corporate value. Journal of Financial Economics, 27(2), 595-612. http://dx.doi.org/10.1016/0304-405X(90)90069-C

Miller, S., \& Shamsie, J. (2001). Learning across the life cycle: Experimentation and performance among the hollywood studio heads. Strategic Management Journal, 22(8), 725-745. http://dx.doi.org./10.1002/smj.171

Millstein, I. M., \& MacAvoy, P. W. (1998). The Active Board of Directors and Performance of the Large Publicly Traded Corporation. Columbia Law Review, 98, 1283-1321.

Mir, S. R., \& Nishat, M. (2004). Corporate governance structure and firm performance in Pakistan-an empirical study. Institute of Business Administration (IBA), Karachi, Working Paper.

Morck, R., Shleifer, A., \& Vishny, R. (1988). Management Ownership and Market Valuation, an Empirical Analysis. Journal of Financial Economics, 20, 293-315.

Myers, S. (1977). Determinants of corporate borrowing. Journal of Financial Economics, 5(2), 147-175. http://dx.doi.org/10.1016/0304-405X(77)90015-0

Nelson, J. (2005). Corporate governance practices, CEO characteristics and firm performance. Journal of Corporate Finance, 11(1-2), 197-228. http://dx.doi.org/10.1016/j.jcorpfin.2003.07.001

Palia, D., Ravid, S. A., \& Wang, C. J. (2008). Founder versus Non-Founder in Large Companies: Financial Incentives and the Call for Regulation. Journal of Regulatory Economics, 33(1), 55-86. http://dx.doi.org/10.1007/s11149-007-9042-z

Raheja, C. G. (2005). Determinants of Board Size and Composition: A Theory of Corporate Boards. The Journal of Financial and Quantitative Analysis, 40(2), 283-306.

Rechner, P., \& Dalton, D. (1991). CEO duality and organizational performance: A longitudinal analysis. Strategic Management Journal, 12(2), 155-160. http://dx.doi.org/10.1002/smj.4250120206

Rosenstein, S., \& Wyatt, J. G. (1990). Outside Directors, Board Independence, and Shareholder Wealth. Journal of Financial Economics, 26, 175-192.

Sanda, A., Mikailu, A. S., \& Garba, T. (2005). Corporate governance mechanisms and firm financial performance in Nigeria. AERC Research Paper 149, African Economic Research Consortium, Nairobi.

Serfling, M. A. (2012). CEO Age, Underinvestment, and Agency Costs. Eller College of Management, University of Arizona.

Shleifer, A., \& Vishny, R.W. (1997). A Survey of Corporate Governance. Journal of Finance, 52(2), 737-83.

Villalonga, B., \& Amit, R. (2006). How do family ownership, management, and control affect firm value? Journal of Financial Economics, 80(2), 385-417. http://dx.doi.org/10.1016/j.jineco.2004.12.005

Weir, C., \& Laing, D. (2001). Governance structures, director independence and corporate performance in the UK. European Business Review, 13(2), 86-95. http://dx.doi.org/10.1108/09555340110385254

Yermack, D. (1996). Higher market valuation of companies with a small board of directors. Journal of Financial Economics, 40(2), 186. http://dx.doi.org/10.1016/0304-405X(95)00844-5

\section{Notes}

Note 1. If $\mathrm{Y}=$ Firm performance, $\mathrm{X}=$ the fraction of shares held by the insiders from the total shares, and $\mathrm{X}^{2}=$ the fraction of shares held by the insiders from the total shares squared, and taking the coefficients of $\mathrm{X}$ and $\mathrm{X}^{2}$ under Tobin's $\mathrm{Q}$ specification, then: $\mathrm{Y}=6.33 * \mathrm{X}+\left(-8.89 * \mathrm{X}^{2}\right) . \mathrm{dY} / \mathrm{dX}=6.33+2 *(-8.89 * \mathrm{X})=6.33-17.79 * \mathrm{X}$. Now solving for optimal value: $6.33-17.79 * X=0 \backslash 17.79 * X=6,33$, then, $X=35.58 \%$.

Note 2. If $Y=$ Firm performance, $X=$ the fraction of shares held by the institutional investors' and mutual funds' and $\mathrm{X}^{2}=$ the fraction of shares held by the institutional investors' and mutual funds' squared, and taking the coefficients of $\mathrm{X}$ and $\mathrm{X}^{2}$ under ROA specification, then: $\mathrm{Y}=.19 * \mathrm{X}+\left(-.36 * \mathrm{X}^{2}\right) . \mathrm{dY} / \mathrm{dX}=.19+2 *(-.36 * \mathrm{X})=.19$ $-.73 * X$. Now solving for optimal value: $.19-.73 * X=0 \backslash .73 * X=.19$, then, $X=26.02 \%$. 